Jurnal Warta Lembaga Pengabdian pada Masyarakat

Vol. 22, No. 2, September 2019, hlm. 86-97

p-ISSN: 1410-9344; e-ISSN: 2549-5631

homepage: http://journals.ums.ac.id/index.php/warta

\title{
PENGGUNAAN MEDIA PEMBELAJARAN “TRAINER ARDUINO” UNTUK MENINGKATKAN KEMAMPUAN GURU SMK DI PEKANBARU
}

\author{
${ }^{1}$ Adlian Jefiza, ${ }^{2}$ Finanta Okmayura, ${ }^{2}$ Raja Widya Novchi \\ ${ }^{1}$ Politeknik Negeri Batam, ${ }^{2}$ Universitas Muhammadiyah Riau \\ e-mail: ${ }^{1}$ adlianjefiza@polibatam.ac.id, ${ }^{2}$ finantaokmayura@umri.ac.id, ${ }^{3}$ rajawidya@umri.ac.id
}

\begin{abstract}
Abstrak
Permasalahan yang terjadi adalah, kurangnya minat siswa SMP untuk melanjutkan studi ke SMK Teknologi Elektronika. Untuk meminimalisir permasalahan tersebut, ada beberapa aspek yang harus ditingkatkan, salah satunya dengan meningkatkan kompetensi Sumber Daya Manusia (Guru) dalam perkembangan dunia elektronika. Salah satu cara meningkatkan kompetensi guru adalah dengan memberikan pelatihan trainer mikrokontroler tipe Arduino yang dilengkapi sensor-sensor sebagai media ajar bagi guru. Kegiatan pelatihan penggunaan trainer mikrokontroler melibatkan 15 orang Guru SMK di Pekanbaru. Sasaran kegiatan kedepannya mampu meningkatkan kualitas guru, kualitas lulusan SMK, dan menambah minat siswa terhadap SMK Teknologi bidang Elektronika. Output yang hasilkan pada kegiatan pelatihan media ajar trainer Arduino adalah terdapat meningkatkan kualitas guru SMK Teknologi khususnya bidang Elektronika sebesar 24,41\%. Peningkatan kompetensi guru dilihat berdasarkan hasil Pretest dan Evaluasi kegiatan.
\end{abstract}

Kata kunci: Pelatihan, Trainer Arduino, Kompetensi Guru

\begin{abstract}
The problem that occurs is, the lack of interest in junior high school students to continue their studies at the Electronics Technology Vocational School. To minimize these problems, there are several aspects that must be improved, one of them is by increasing the competence of Human Resources (Teachers) in the development of the electronics world. One way to improve teacher competency is to provide Arduino type microcontroller trainer training which is equipped with sensors as a teaching medium for teachers. Training activities on the use of microcontroller trainers involved 15 vocational teacher in Pekanbaru. The target of future activities is to be able to improve the quality of teachers, the quality of vocational graduates, and increase students' interest in vocational technology in the field of electronics. The output produced in the Arduino trainer instructional media training activities is that there is an increase in the quality of vocational technology teachers especially in the electronics field by $24.41 \%$. Teacher competency improvement is seen based on the results of Pretest and Evaluation of activities.
\end{abstract}

Keywords: Pelatihan, Trainer Arduino, Kompetensi Guru 


\section{PENDAHULUAN}

Perkembangan dunia Elektronika dalam dunia pendidikan pada zaman now ini mengalami sedikit kemunduran. Dengan semakin favoritnya sekolah dengan program studi Komputer, membuat sekolah dengan latar belakang elektronika semakin tertinggal. Hal ini juga terjadi di kota Pekanbaru. Sekolah teknologi bidang elektronika yang terdiri dari prodi Teknik Audio Video, Teknik Elektronika Industri dan Mekatronika semakin hari semakin kurang diminaati. Sudah seharusnya terdapat inovasi terbaru untuk meningkatkan minat siswa terhadap sekolah teknologi, khususnya bidang elektronika

Di kota Pekanbaru, terdapat sekitar sepuluh (10) buah SMK Teknologi bidang Elektronika. Jumlah sekolah teknologi yang tergolong banyak. Sekolah-sekolah ini terdiri dari tujuh SMK yang memiliki program studi Teknik Audio Video, satu sekolah yang memiliki program studi Mekatronika, dan tiga sekolah yang memiliki program studi Teknik Elektronika Industri. Umumnya program studi tersebut sudah berakreditasi A. Ini berarti program studi Teknologi bidang Elektronika merupakan program studi unggulan. Sudah seharusnya program studi tersebut merupakan unggulan dari setiap sekolah. Untuk data sekolah dan program studi Teknologi bidang Elektronika dapat dilihat pada Tabel 1

Menurut survey yang telah dilakukan ke beberapa sekolah, jumlah siswa untuk program studi Teknik Audio Video, Teknik Elektronika, Mekatronika dan Rekayasa Perangkat Lunak selalu menurun tiap tahunnya. Bahkan beberapa SMK telah menutup jurusan TAV, seperti SMK Hasanah, SMK Darel Hikmah dan SMK Dwi Sejahtera. Begitu juga pada SMK Multi Mekanik Masmur pada tahun 2012 pernah vakum untuk program studi Teknik Audio Video.

Setelah melakukan wawancara dengan salah satu guru Teknik Audio Video di SMK Multi Mekanik Masmur, penyebab turunnya peminat program studi Teknik Audio Video, Teknik Elektronika, maupun Mekatronika khususnya di sekolah swasta dikarenakan kompetensi guru terhadap perkembangan Industri elektronika masih berpatokan pada kurikulum yang lama (ex:perakitan sound system). Sedangkan pada zaman sekarang, semua peralatan elektronik sudah berbasis otomasi. Maka dari itu, dibutuhkan peningkatan kompetensi guru.

Menurut narasumber tersebut yang merupakan ketua program studi Teknik Audio Video dan Rekayasa Perangkat Lunak menambahkan bahwa beberapa sarana praktek di sekolah belum memenuhi untuk mengikuti zaman otomasi elektronika.

Untuk menghidupkan lagi minatsiswa dalam dunia Elektronika, ada beberapa aspek yang harus diperhatikan. Yang pertama dari sarana dan prasarana sekolah. Setiap sekolah harus mempunyai perangkat yang mendukung dalam praktek siswa sesuai dengan perkembangan zaman. Yang kedua berkaitan dengan sumber

Tabel 1. Daftar SMK di Pekanbaru

\begin{tabular}{cllc}
\hline No & \multicolumn{1}{c}{ Nama Sekolah } & \multicolumn{1}{c}{ Program Studi } & Akreditasi (2017) \\
\hline 1. & SMK N 2 Pekanbaru & - Teknik Audio Video & $\mathrm{A}$ \\
& & - Teknik Elektronika Industri & $\mathrm{A}$ \\
2. SMK N 5 Pekanbaru & - Teknik Audio Video & - \\
3. SMK N 6 Pekanbaru & - Mekatronika & $\mathrm{A}$ \\
4. SMK Multi Mekanik Masmur & - Teknik Audio Video & $\mathrm{A}$ \\
5. SMK Taruna Satria & - Teknik Audio Video & $\mathrm{A}$ \\
6. SMK Taruna Mandiri & - Teknik Audio Video & $\mathrm{A}$ \\
7. SMK Muhammadiyah 1 & - Teknik Audio Video & $\mathrm{A}$ \\
8. SMK Kansai & - Teknik Elektronika Industri & $\mathrm{A}$ \\
9. SMK Telkom & - Teknik Elektronika Industri & $\mathrm{B}$ \\
10. SMK Dwi Sejahtera & - Teknik Audio Video & $\mathrm{B}$ \\
\hline
\end{tabular}


daya manusia. Dalam hal ini adalah guru yang mengajar Elektronika. Beberapa tenaga pendidik di SMK di kota Pekanbaru masih banyak yang tidak sesuai latar belakang pendidikan dengan mata pelajaran yang diajar. Selain itu, minat belajar tenaga pendidik dalam mengalami ilmu pengetahuan yang terbaru juga perlu ditingkatkan. Dengan perkembangan dunia Teknologi bidang Elektronika, diharuskan guru juga mengikuti dan mempelajari semua teknologi terbaru. Langkah terakhir untuk meningkatkan minat siswa ke program studi elektronika adalah dengan melakukan promosi.

Sudah seharusnya setiap sekolah harus mengikuti perkembangan dunia elektronika, demi meningkatkan kualitas siswa. Dengan demikian, peminatan siswa yang akan masuk ke SMK Teknologi akan semakin meningkat. Oleh karena permasalahan tersebut, diberikanlah pelatihan peningkatan kompetensi guru SMK di Pekanbaru dengan menggunakan trainer Arduino.

Salah satu contoh sarana yang harus ditingkatkan oleh pihak sekolah Teknologi bidang Elektronika adalah dengan pemanfaatan Mikroprocessor dan Mikrokontroler dalam bidang otomasi. Dizaman sekarang ini, komponen elektronika sudah dalam bentuk chip. Sudah jarang ditemui didalam sebuah perangkat elektronik yang terdapat kumpulan komponen elektronika dasar. Semuanya sudah dalam bentuk IC dan module elektronik (Jefiza et al., 2017). Seperti halnya mikrokontroler, dahulu para peminat dunia elektronika masih menggunakan AT Mega. Penggunaan chip AT Mega ini menggunakan aplikasi downloader dan perangkat tambahan untuk memasukkan perintah. Namun pada saat sekarang ini, chip AT Mega sudah dimodifikasi menjadi sebuah modul mikrokontroler yang biasa disebut dengan Arduino(Onibonoje et al., 2015).

Menurut Nurhadi Budi Santoso dalam modul Penembangan Keprofesian Berkelanjutan untuk Kompetensi Keahlian Teknik Audio Video Sekolah Menengah Kejuruan pada bidang professional Teknik Mikroprocessor dan Pemrograman menjelaskan bahwa Guru perlu meningkatkan kompetensi profesionalismenya terkait dengan disiplin ilmu elektronika, khususnya pada topik Teknik Mikroprosessor dan Pemrograman para guru harus terus dimantapkan, ditingkatkan, dan dikembangkan. Pemantapan tersebut tidak hanya terkait pengetahuan konseptual dan prosedural tetapi juga pemantapan kemampuan guru dalam menyelesaikan proses pembelajaran Teknik Mikroprosessor dan Pemrograman di dalam kelas dan masalah dunia nyata atau kehidupan sehari-hari dengan tidak meninggalkan penguatan pendidikan karakter (PPK). Hal itu tertuang dalam Permendiknas No 16 Tahun 2007 tentang Standar Kompetensi Guru pada Kompetensi Profesional pada pasal 1 ayat (1) menyatakan bahwa setiap guru wajib memenuhi standar kualifikasi akademik dan kompetensi guru yang berlaku secara nasional.

Dengan meningkat kualitas Sumber Daya Manusia dalam hal ini kualitas guru dalam pengajaran Teknik Mikroprosesor dan mikrokontroler, perlu sekiranya diberikan workshop dan pelatihan guru tentang mikroprosesor dan mikrokontroler khususnya trainer Arduino yang dilengkapi dengan beberapa sensor. Diharapkan dengan meningkatkan SDM ini dapat meningkatkan kualitas sekolah dan menambah minat siswa untuk bergabung ke sekolah Teknologi bidang Elektronika.

\section{METODE PELAKSANAAN}

Beberapa rencana kegiatan yang akan dilakukan dalam kegiatan yaitu: sosialisasi, perakitan, pelatihan, dan workshop secara terstruktur terhadap berbagai hal yang menjadi kendala dalam upaya menikatkan minat siswa dalam bidang elektronika.

\section{Sosialisasi Program}

Permasalahan yang diangkat pada program kemitraan masyarakat stimulus ini diperoleh berdasarkan wawancara dan observasi yang dilakukan tim dosen dibeberapa sekolah teknologi di Pekanbaru. Wawancara dilakukan di SMK Multimekanik Masmur dan SMK Taruna Mandiri Pekanbaru. Kedua sekolah tersebut dianggap sebagai sumber informasi yang valid karena memiliki program studi teknik audio video. Bahkan SMK Multi Mekanik Masmur pernah menutup jurusan TAV selama satu angkatan. Untuk observasi dilakukan di beberapa sekolah dengan mengamati jumlah siswa pada 
program studi TAV, Teknik Mekatronika, Teknik Elektro Industri.

Setelah melakukan observasi, dirumuskan program dalam meningkatkan minat siswa untuk melanjutkan di sekolah Teknologi. Program yang diajukan berupa pelatihan dan workshop kepada beberapa guru SMK di Pekanbaru dalam memperkenalkan trainer Arduino. Program ini diharapkan dapat meningkatkan kompetensi guru sehingga dapat meningkatkan kualitas dan kuantitas lulusan.

Sosialisasi dilaksanakan di SMK Multi Mekanik Masmur Pekanbaru. Pada sosialisasi, dosen mengusulkan sebuah program kemitraan antara Universitas Muhammadiyah Riau dengan SMK yang bersangkutan berupa pelatihan peningkatan kompetensi guru dengan penggunaan media pembelajaran Trainer Arduino. Program ini disambut baik oleh pihak sekolah. Bapak Yohandra Jamal, S.Pd. selaku kepala SMK Multi Mekanik Masmur sangat mengapresiasi program kemitraan yang diusulkan. Dengan adanya kemitraan antara universitas dan sekolah diharapkan adanya sinergi dari kedua elemen pendidikan.

\section{Trainer Arduino}

Trainer Arduino merupakan media pembelajaran yang dikembangkan menggunakan mikrokontroler Arduino. Trainer Arduino dapat digunakan pada mata pelajaran Dasar Pemrograman, Sisem Digital, Sensor dan Tranduser, dan Mikrokontroler. Selama ini penggunaan mikrokonroler sebagai media pembelajaran di sekolah di pekanbaru masih menggunakan tipe AVR. Diharapkan dengan adanya pembaharuan ini, dapat mengupgrade kompetensi guru yang selama ini masih berdasarkan media yang kuno dalam pembelajaran.

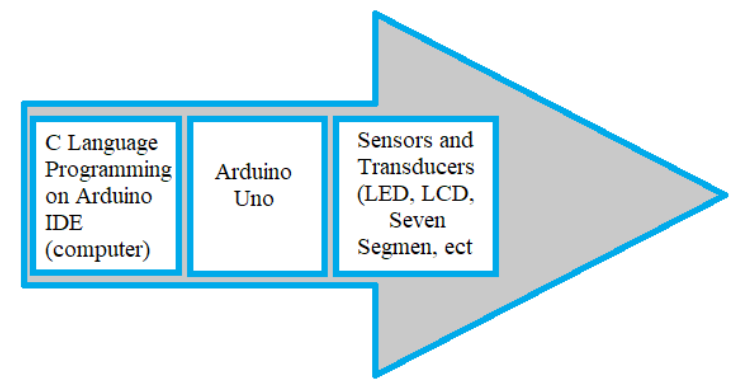

Gambar 1. Sistem Kerja Trainer Arduino
Trainer Arduino terdiri dari beberapa sensor dan tranduser. Komponen penting pada trainer terseb ut adalah Mikrokontroler Arduino tipe Uno. Ada banyak tipe Arduino tergantung ukuran dan penggunaanya. Ada tipe Arduino Lilipad, Arduino Uno, Arduino Nano, Arduino Mini dan lain sebagainya. Yang menjadi pembeda pada beberapa jenis Arduino adalah kemampuan daya kerja dan daya simpannya. Adapun cara kerja dari trainer Arduino dapat dilihat pada Gambar 1.

Pada Trainer Arduino, penggunaan sensor dan tranduser menjadi acuan sebagai media pembelajaran. Disana pengguna akan mempelajari pemrograman dengan menggunakan Bahasa C[4]. Jadi pada penerapannya, sensor dan tranduser dapat bekerja dengan cara pengguna memodifikasi perintah-perintah dalam bentuk Bahasa pemrograman dan dikirimkan ke Arduino. Gambar 2 merupakan bentuk dari Arduino Uno

Gambar 2 merupakan Arduino tipe Uno yang banyak digunakan dalam dunia otomasi. Arduino Uno memiliki 14 pin digital dan 6 pin analog. Pada pin digital, terdapat 6 pin yang dapat digunakan sebagai PWM. Arduino Uno memiliki tengangan operasi sebesar $5 \mathrm{~V}$.

\section{Perakitan Trainer Arduino}

Perakitan trainer Arduino dilaksanakan tujuh kali dimulai bulan Mei 2019 sampai Juni 2019.

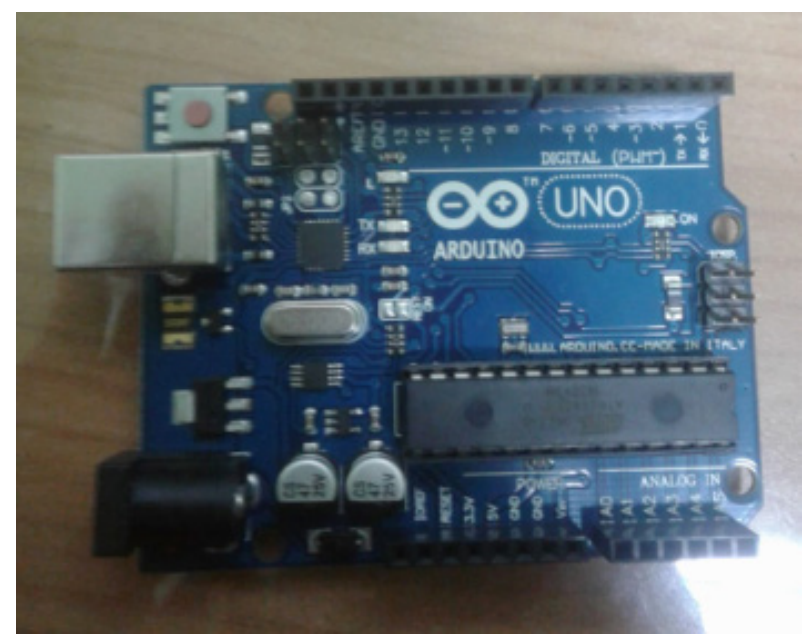

Gambar 2. ArduinoUno 


\section{Perakitan pertama}

Pekerjaan pertama dalam perakitan trainer Arduino adalah pembuatan layout PCB. Pembuatan layout dilaksanakan di Kampus 2 UMRI dengan melibatkan mahasiswa Pendidikan Vokasional Teknik Elektronika. Pembuatan layout dilaksanakan pada tanggal 8 dan 9 Mei 2019.

\section{Perakitan Kedua}

Perakitan kedua bertujuan untuk pemasangan sensor ke layout yang sudah dibuat pada perakitan pertama. Ada beberapa sensor yang dipasangkan ke layout, sisanya dipasangkan ke project board. Sensor yang dipasangkan ke layout diantaranya sensor LDR, Seven Segment, LED, dan Buzzer. Sedangkan sensor lainnya dipasangkan di akrilik dan di project board. Perakitan sensor dilaksakan di Kampus 2 Umri pada tanggal 25-26 Mei 2019. Perakitan diperbatukan oleh mahasiswa Pendidikan Vokasional Teknik Elektronika.

\section{Perakitan Ketiga}

Perakitan ketiga bertujuan untuk membuat program setiap sensor. Program yang dibuat menggunakan pada komputer menggunakan aplikasi Arduino. Pemrograman Arduino menggunakan bahasa $\mathrm{C}$ yang merupakan bahasa tingkat tinggi. Pemrograma dilaksanakan di kampus 2 Umri pada tanggal 21 dan 22 Juni 2019. Program yang dibuat nantinya dapat digunakan untuk pembuatan modul praktikum.

\section{Pengujian Trainer Arduino}

Pengujian Trainer Arduino dilaksanakan pada tanggal 26 Juni 2019. Pengujian dilaksanakan oleh seluruh tim pengabdian dan mahasiswa yang bersangkutan. Pengujian bertujuan untuk melihat alat yang dibuat sudah berjalan dengan baik atau tidak. Hasil dari pengujian yang dilaksanakan terdapat beberapa kesalahan dalam pemrograman sehingga sensor tidak bekerja dengan baik. Tindakan yang dilakukan adalah merevisi program yang telah dibuat sebelumnya. Selain pengujian trainer, juga dilakukan improvisasi kodingan, dimana dibuat sebuah program yang menggunakan beberapa sensor. Mekanisme kerja pada trainer tersebut adalah, user diharapkan merakit rangkaian menggunakan mikrokontroler dan sensor yang digunakan menggunakan kabel penghubung (jumper). Hal ini lebih efisien karena user dapat mengkombinasikan sensor yang akan digunakan.

Pengujian meliputi tahapan pengujian sensor dan pengujian program. Pengujian sensor bertujuan untuk melihat apakah sensor bekerja dengan baik. Sensor yang digunakan harus mendapatkan hasil yang presisi. Sedangkan untuk pengujian program bertujuan untuk melihat apakah terdapat algoritma yang belum sesuai atau terdapat kesalahan program.

Pada trainer Arduino, Arduino dapat dihubungkan pada beberapa sensor yang tersedia, diantaranya ada LED, LDR, LCD, Seven Segment, sensor Suhu, sensor timer, Dot Matrix dan sensor kelembaban. Gamaran trainer Arduino yang digunakan pada pelatihan dapat dilihat pada Gambar 3.

Gambar 3 merupakan bentuk jadi dari trainer Arduino yang digunakan pada pelatihan peningkatan kompetensi guru di SMK Multi Mekanik Masmur.

\section{Data Pengabdian}

Data yang diambil dalam pengabdian ini adalah hasil Pretest, Postest, dan evaluasi yang diberikan kepada partisipan. Hasil pretest dilakukan sebelum dilaksanakn pelatihan, sedangkan posttest dan evaluasi dilaksanakan sesudah pelatihan trainer Arduino. Adapun roadmap dalam penelitian ini dapat dilihat pada Gambar 4

\section{Pretest}

Penilaian dengan prosedur pre test adalah suatu bentuk pertanyaan, yang dilontarkan sebelum memulai suatu pelajaran. Pertanyaan yang ditanya adalah materi yang akan diajar pada saat tersebut (materi baru). Pemberian pretest biasanya dilakukan di awal pembukaan pelajaran. Tujuan diberikan pretest pada penelitian ini adalah untuk melihat sejauh mana pengetahuan partisipan tentang mikrokontroler, trainer arduino dan sensor tranduser sebelum diberikan perlakuan (pelatihan). Setiap peserta diberikan lembar soal pilihan ganda yang terdiri dari 40 butir soal. Soal terdiri dari 15 soal mikrokontroler, 5 soal Arduino IDE, 5 soal pemrograman dan 15 soal sensor dan tranduser 


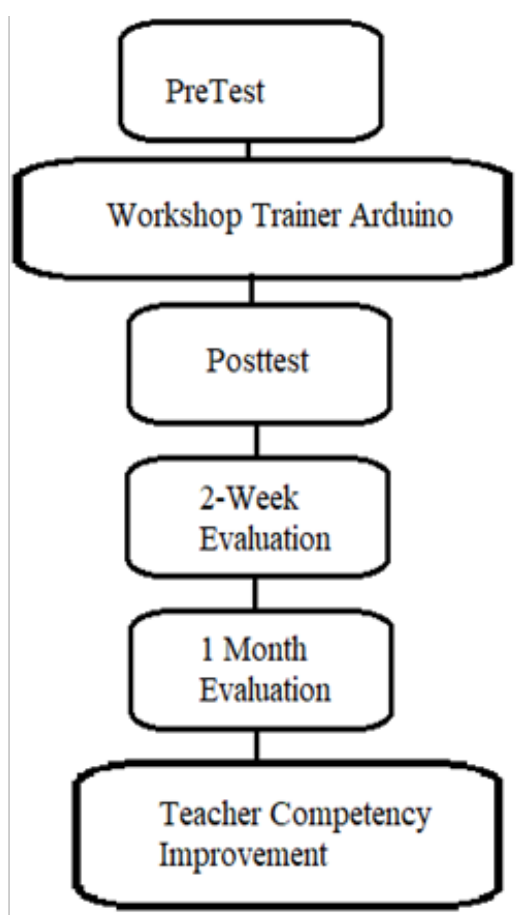

Gambar 3 Road Map Kegiatan

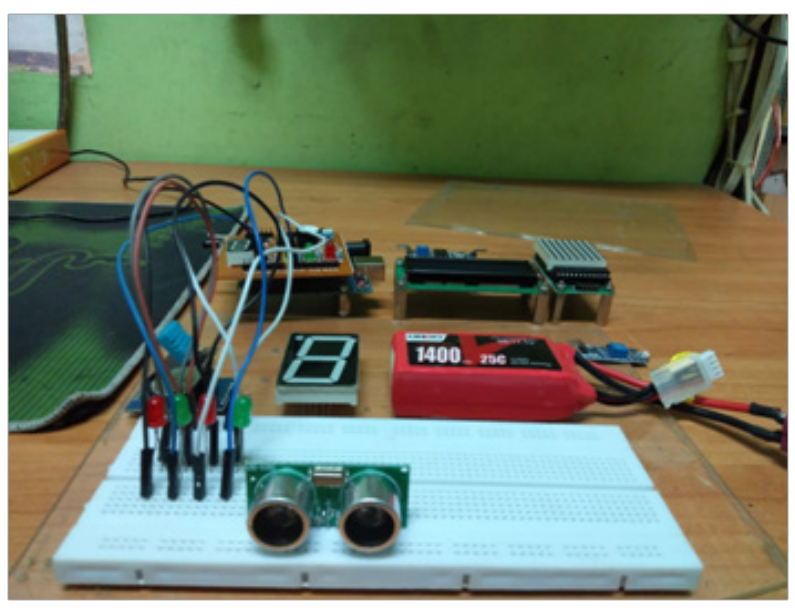

Gambar 4. Trainer Arduino

\section{Pelatihan penggunaan trainer Arduino}

Pelatihan dilaksanakan di Lab Komputer SMKMultimekanik Masmur Pekanbaru, Pelatihan berlangsung selama 1 hari peluh. Pelatihan diikui oleh 15 partisipan yang terdiri dari guru dan laboran. Partisipan berasal dari program studi Teknik Audio Video, Teknik Rekayasa Perangkat Lunak, dan Teknik Kompunter Jaringan.

Pelatihan berlangsung selama 1 hari, dimulai dari jam 09.00 WIB, sampai jam 17.00 WIB. Sebelum pelatihan dimulai, peserta diberikan Pretest selama 30 menit untuk melihat sejauh mana kompetensi guru terhadap mikrokontroler jenis Arduino dan sensor tranduser. Adapun materi yang disampaikan selama pelatihan dapat dilihat pada Tabel 1. Setelah diberikan pelatihan, kegiatan ditutup dengan posttest di sesi terakhir.

\section{Postest}

Penilaian dengan Prosedur post test adalah bentuk pertanyaan yang diberikan setelah pelajaran/materi telah disampaikan. Dengan kata lain, post test adalah evaluasi akhir saat materi yang di ajarkan pada hari itu telah diberikan yang mana seorang guru memberikan post test dengan maksud apakah murid sudah mengerti dan memahami mengenai materi yang baru saja diberikan pada hari itu. Postest bertujuan untuk melihat hasil dari kegiatan yang telah dilaksanakan. Hasil dari postest tersebut dapat memberikan informasi apakah tujuan pelaksanaan kegiatan telah tercapai atau belum. Pada penelitian ini, butir soal yang dijadikan posttest sama dengan soal pada pretest. Setiap peserta diberikan lembar soal pilihan ganda yang terdiri dari 40 butir soal. Soal terdiri dari 15 soal mikrokontroler, 5 soal

Arduino IDE, 5 soal pemrograman dan 15 soal sensor dan tranduser. Pemberian posttest ini diharapkan dapat melihat peningkatan kompetensi guru setelah diberikan pelatihan trainer Arduino. Setelah pelatihan dilaksanakan dilaksanakan, trainer Arduino beserta jobsheet diserahkan ke pihak sekolah untuk dipelajari secara mandiri.

\section{Evaluasi 2 Minggu pasca pelatihan}

Evaluasi dilakukan untuk melihat apakah guru mempelajari trainer tersebut secara mandiri disekolah. Tindakan evaluasi kegiatan pertama dilaksanakan 2 minggu sesudah diberikan pelatihan. Partisipan diberikan lembar soal untuk di jawab. Soal yang diberikan sama dengan soal pretest ataupun posttest. Diharapkan pada evaluasi 2 minggu ini terdapat peningkatan kompensi guru jika dibandingkan hasil tes pada posttest sebelumnya.

\section{Evaluasi 1 Bulan pasca pelatihan}

Evaluasi satu bulan pasca pelatihan bertujuan untuk melihat sejauhmana pencapaian peningkatan kompetensi guru setelah 1 bulan pasca pelatihan. Dengan trainer yang sudah difasilitasi di sekolah, diharapkan adanya 
peningkatan yang signifikan pada kompetensi guru setelah satu bulan pelaksanaan pelatihan

\section{Kompetensi Guru}

Guru wajib memiliki kualifikasi, kompetensi, sertifikasi pendidik, sehat jasmani dan rohani. Menurut PP RI No 19/2005 tentang Standar Nasional Pendidikan Pasal 28 pendidik adalah agen pembelajaran yang harus memiliki empat kompetensi yakni kompetensi pedagogik, kepribadian, profesional, dan sosial. Dalam konteks itu kompetensi guru dapat diartikan sebagai kebulatan pengetahuan, keterampilan dan sikap yang diwujudkan dalam bentuk perangkat tindakan cerdas dan penuh tanggung jawab yang dimiliki seorang calon guru untuk memangku jabatan guru sebagai profesi.

Kompetensi pedagogik meliputi sub kompetensi (1) memahami karakteristik peserta didik dari aspek fisik, sosial, moral, kultural, emosional dan intelektual, (2) memahami latar belakang keluarga dan masyarakat peserta didik dan kebutuhan belajar dalam konteks kebhinekaan budaya, (3) memahami gaya belajar dan kesulitan belajar peserta didik, (4) memfasilitasi pengembangan potensi peserta didik, (5) menguasai teori dan prinsip belajar serta pembelajaran yang mendidik, (6) mengembangkan kurikulum yang mendorong keterlibatan peserta didik dalam pembelajaran, (7) merancang pembelajaran yang mendidik, (8) melaksanakan pembelajaran yang mendidik, (9) mengevaluasi proses dan hasil pembelajaran

Kompetensi kepribadian meliputi sub kompetensi (1) menampilkan diri sebagai pribadi yang mantap, stabil, dewasa, arif, dan berwibawa, (2) menampilkan diri sebagai pribadi yang berakhlak mulia dan sebagai teladan bagi peserta didik dan masyarakat, (3) mengevaluasi kinerja sendiri, (4) mengembangkan diri berkelanjutan. Kompetensi profesional meliputi sub kompetensi: (1) menguasai substansi bidang studi dan metodologi keilmuannya, (2) menguasai struktur dan materi kurikulum bidang studi, (3) menguasai dan memanfaatkan teknologi informasi dan komunikasi dalam pembelajaran, (4) mengorganisasikan materi kurikulum bidang studi, (5) meningkatkan kualitas pembelajaran melalui penelitian tindakan kelas Kompetensi sosial meliputi subkompetensi: (1) berkomunikasi secara efektif dan empatik dengan peserta didik, orang tua peserta didik, sesama pendidik, tenaga kependidikan dan masyarakat, (2) berkontribusi terhadap pengembangan pendidikan disekolah dan masyarakat, (3) berkontribusi terhadap pengembangan pendidikan di tingkat lokal, regional, nasional dan global, (4) memanfaatkan teknologi informasi dan komunikasi untuk berkomunikasi dan pengembangan diri.

\section{HASIL DAN PEMBAHASAN}

Pengenalan mikrokontroler dan mikroprosesor dilaksanakan di Lab Komputer SMK Multimekanik Masmur Pekanbaru. Kegiatan dilaksanakan pada tanggal 16 Juli 2019 yang dimulai jam 09.00 sampai jam 11.30 WIB. Materi yang disampaikan berkaitan dengan penerapan mikrokontroler dalam Revolusi Industri V 4.0. Kuliah umum diikuti sebanyak 15 orang yang terdiri dari guru dan laboran.

Registrasi peserta dimulai jam 08.00 WIB. Peserta disediakan snack sebagai sarapan pagi agar peserta bersemangat dalam mengikuti rangkaian kegiatan. Dimeja registrasi, mahasiswa ditugaskan untuk mengarahkan peserta yang baru datang.

Sebelum pelaksaan kuliah umum, peserta terlebih dahulu diberikan pretest untuk melihat sejauh mana pengetahuan peserta terhadap mikrokontroler. Soal pretest berisikan materi-materi tentang mikrokontroler dan sensor transudser. Soal berupa pilihan ganda sebanyak 20 butir. Hasil pretest tersebut menunjukkan bahwa pemahaman guru terhadap mikrokontroler masih rendah. Guru masih mengandalkan penggunaan IC dalam sistem kendali.

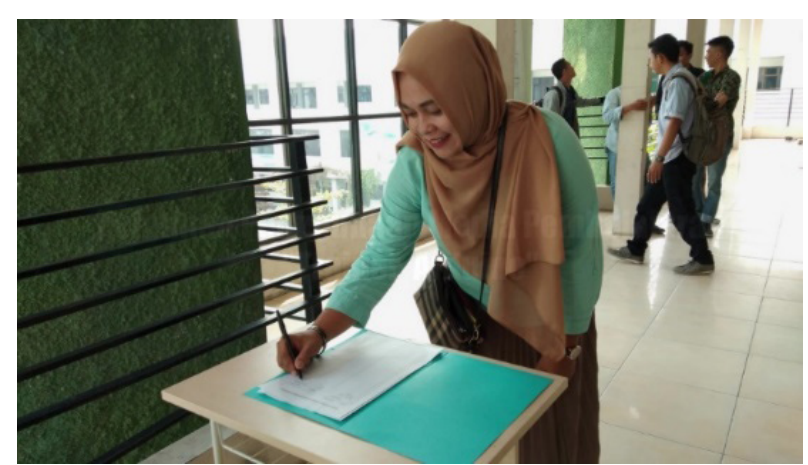

Gambar 5. Registrasi Peserta 


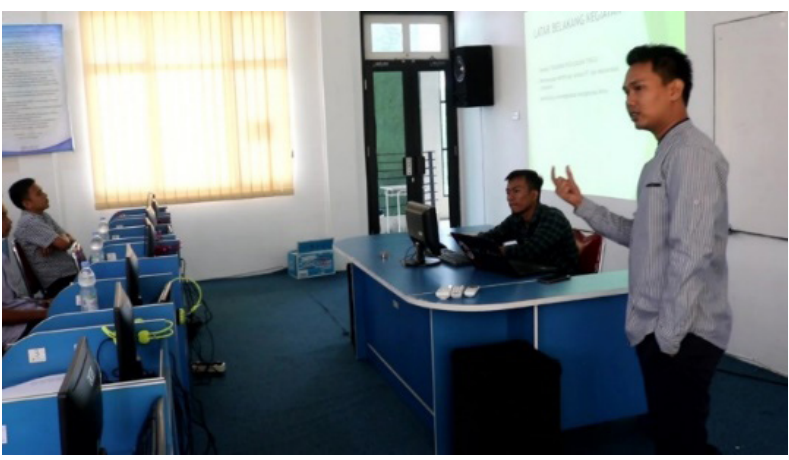

Gambar 6. Penyampaian Materi Mikrokontroler

Kuliah umum diawali dengan menampilkan video singkat tentang penerapan mikrokontroler. Hal ini bertujuan untukmeransang rasaingin tahu peserta terhadap pelatihan yang dilaksanakan. Dari video tersebut, terlihat rasa antusias peserta terhadap kemajuan teknologi otomasi yang menggunakan system mikrokontroler.

Setelah menyaksikan video, peserta diberikan materi mikrokontroler dan mikroprosesor. Pemateri menjelaskan perbedaan antara mikroprosesor dan mikrokontroler. Ternyata banyak peserta yang belum memahami perbedaan dasar antara mikroprosesor dan mikrokontroler. Materi dilanjutkan dengan pengenalan mikrokontroler dan jenis- jenisnya. Materi ditutup dengan cara pemrograman dari mikrokontroler.

Sekitar jam 10.30, sesi kuliah umum selesai, dan dilanjutkan dengan sesi tanya jawab. Peserta dipersilakan untuk bertanya dan pemateri akan coba menjawab sebaik mungkin. Total ada 7 pertanyaan yang disampaikan peserta selama sesi tanya jawab berlangsung. Sebagian besar pertanyaan yang diajukan adalah bagaiman cara pengoperasian dari mikrokontroler tersebut. Sesi tanya jawab selesai jam 11.30, bertepatan dengan waktu istirahat.

Di akhir sesi kuliah umum, peserta diberikan posttest untuk melihat apakah ada peningkatan kompetensi guru setelah kegiatan penyampaian materi dilaksanakan. Posttest diberikan dengan memberikan pertanyaan yang sama dengan per test. Kegiatan evaluasi ini dilaksanakan selama 30 menit sampai jam 12.00 WIB.

\section{Workshop Trainer Arduino}

Workshop trainer Arduino dilaksanakan setelah jam istirahat sesudah kuliah umum.
Workshop dilaksanakan di Lab Komputer SMK Multi Mekanik Masmur Pekanbaru. Praktek yang dilakukan berdasarkan materi yang sudah diberikan saat kuliah umum.

Kegiatan workshop dipandu oleh ketua tim. Kegiatan workshop diikuti sekitar 15 peserta yang terdiri dari guru dan teknisi laboran. Workshop dimulai pada pukul 13.30 WIB. Untuk sesi pertama, dimulai dengan pengenalan aplikasi Arduino. Sesi pertama berlangsung selama 30 menit.

Sesi kedua dimulai dengan pemrograman LED selama 30 menit. Peserta diminta untuk menulis program pada aplikasi Arduino IDE berdasarkan jobsheet yang tersedia. Peserta mengikuti langkah-langkah pemrograman yang sudah disusun secara sistematis. Setelah program dituliskan, program di upload kan ke mikrokontroler. Terlihat antusias peserta ketika melihat hasil program yang telah dikerjakannya. Ada beberapa peserta yang menemukan kesalahan dalam pemrograman, seperti salah pengetikan ataupun kendala koneksi mikrokontroler.

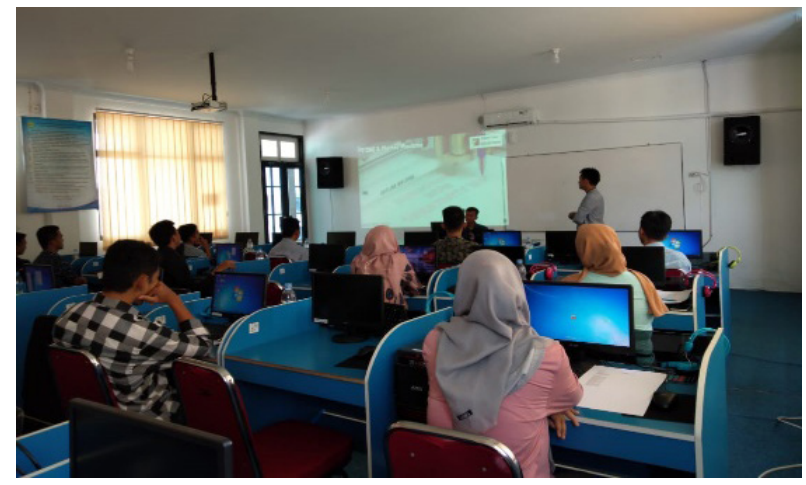

Gambar 7. Penayangan Video Pemanfaatan Arduino

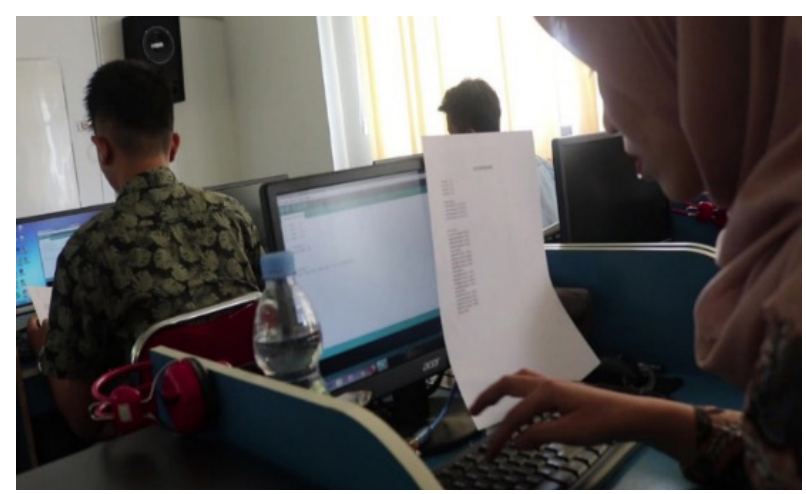

Gambar 8. Workshop Trainer Arduino

Warta LPM, Vol. 22, No. 2, September 2019 
Tabel 2. Jadwal Kegiatan Workshop

\begin{tabular}{clll}
\hline No & Kegiatan & Jam & Instruktur \\
\hline 1 & Pengenalan Arduino IDE & $13.30-13.45$ & Adlian Jefiza \\
2 & Pemrograman LED & $13.45-14.05$ & Adlian Jefiza \\
3 & Pemrograman LCD & $14.05-14.25$ & Adlian Jefiza \\
4 & Pemrograman Sensor Ultrasonic & $14.25-14.45$ & Adlian Jefiza \\
5 & Pemrograman Sensot LDR & $14.45-15.05$ & Finanta Okmayura \\
6 & Pemrograman Sensor Suhu & $15.05-15.20$ & Finanta Okmayura \\
7 & Water Break & $15.20-15.45$ & Istirahat \\
8 & Pemrograman Seven Segment & $15.45-16.05$ & Finanta Okmayura \\
9 & Pemrograman gabungan beberapa sensor & $16.05-16.25$ & Finanta Okmayura \\
\hline
\end{tabular}

Setelah workshop pemrograman selesai, peserta diberikan postest untuk melihat pencapaian peningkatan kompetensi guru. Kegiatan diakhiri dengan sesi foto bersama.

\section{Peningkatan Kompetensi Guru}

Berdasarkan Undang-Undang Nomor 14 Tahun 2005 tentang Guru dan Dosen, pada pasal 10 ayat (1) menyatakan bahwa "Kompetensi guru sebagaimana dimaksud dalam Pasal 8 meliputi kompetensi pedagogik, kompetensi kepribadian, kompetensi sosial, dan kompetensi profesional yang diperoleh melalui pendidikan profesi". Ada beberapa indikator pencapaian kegiatan yang akan dijadikan acuan dalam melihat peningkatan kompetensi guru dalam pelaksanaan pengabdian ini. Indikator yang diambil sebagai acuan dalam peningkatan kompetensi guru yaitu komptensi pedagogic dan kompetensi professional. Kompetensi Pedagogik adalah kemampuan pemahaman terhadap peserta didik, perancangan dan pelaksanaan pembelajaran, evaluasi hasil belajar, dan pengembangan peserta didik untuk mengaktualisasikan berbagai potensi yang dimilikinya. Sedangkan kompetensi professional adalah penguasaan materi pembelajaran secara luas dan mendalam, yang mencakup penguasaan materi kurikulum mata pelajaran di sekolah dan substansi keilmuan yang menaungi materinya, serta penguasaan terhadap struktur dan metodologi keilmuannya.

Tabel 3 Hasil Pretest, Posttest dan Evaluasi

\begin{tabular}{cccccc}
\hline No & Name & Pretest & Posttest & 2-Week Evaluation & 1 Month Evaluation \\
\hline 1 & Participant 1 & 52,5 & 72,5 & 75 & 77 \\
2 & Participant 2 & 67,5 & 75 & 77,5 & 80 \\
3 & Participant 3 & 65 & 77,5 & 80 & 80 \\
4 & Participant 4 & 65 & 70 & 75 & 77,5 \\
5 & Participant 5 & 60 & 75 & 77,5 & 80 \\
6 & Participant 6 & 57,5 & 70 & 72,5 & 80 \\
7 & Participant 7 & 70 & 80 & 80 & 85 \\
8 & Participant 8 & 75 & 85 & 90 & 95 \\
9 & Participant 9 & 60 & 80 & 80 & 87,5 \\
10 & Participant 10 & 55 & 65 & 67,5 & 75 \\
11 & Participant 11 & 52,5 & 65 & 67,5 & 75 \\
12 & Participant 12 & 65 & 75 & 80 & 85 \\
13 & Participant 13 & 62,5 & 85 & 85 & 90 \\
14 & Participant 14 & 65 & 80 & 80 & 85 \\
15 & Participant 15 & 70 & 85 & 92,5 & 95 \\
\hline
\end{tabular}




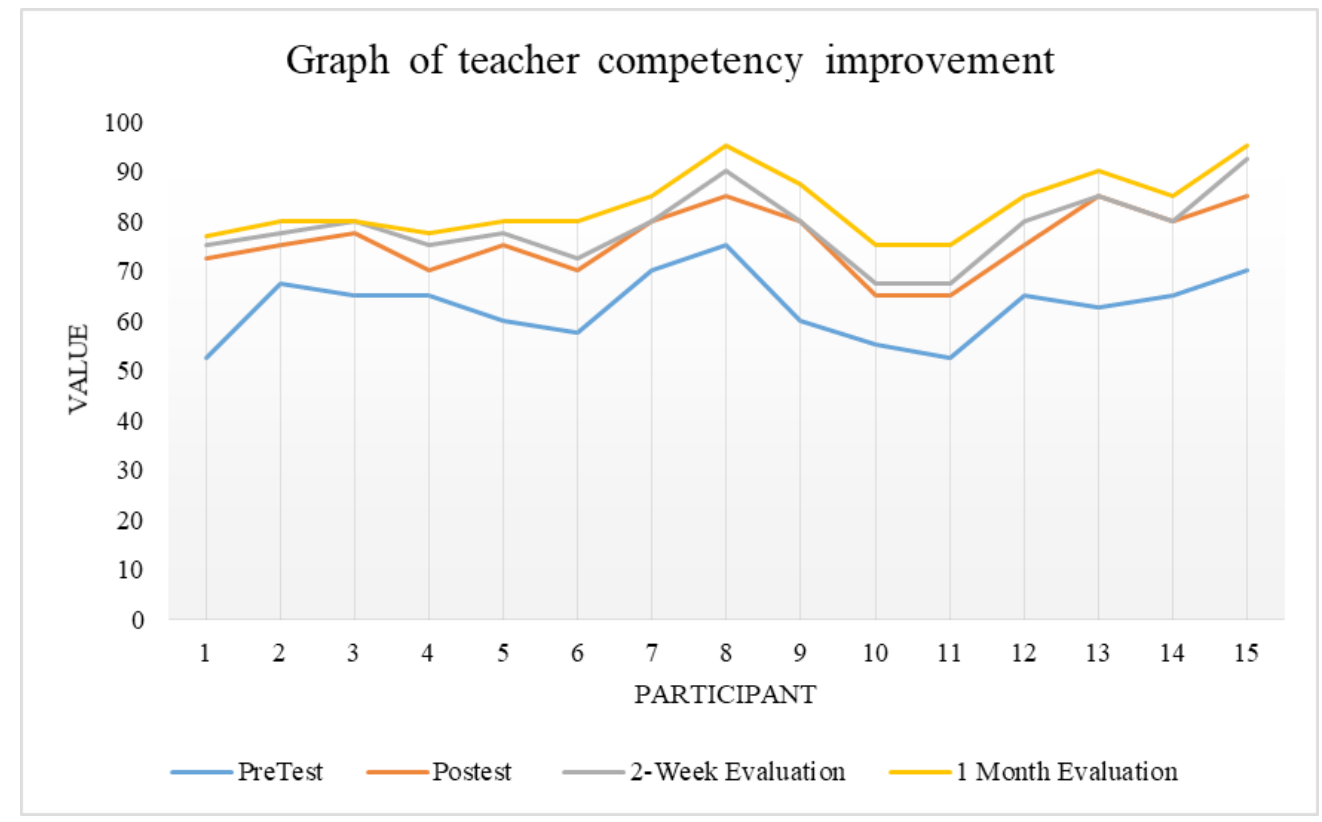

Gambar 9. Peningkatan Kompetensi Guru

Berdasarkan kompetensi pedagogik dan kompetensi professional, disusunlah soal -soal dari materi Trainer Arduino yang dapat dijadikan acuan dalam melihat peningkatan kompetensi guru. Soal disusun sebanyak 40 butir,

Evaluasi bertujuan untuk melihat peningkatan kompetensi guru berdasarkan nilai dari pretest dan postest. Evaluasi juga dilaksanakan 2 minggu dan 1 bulan sesudah kegiatan pengabdian dilaksanakan. Evaluasi dilakukan untuk melihat apakah guru belajar mandiri dengan sarana trainer yang diberikan tim pengabdian. Bentuk evaluasi yang dilaksanakan sama saperti evaluasi disaat pretest. Hasil pretest, postest dan evaluasi dapat dilihat pada tabel 3 .

Dari Tabel 3 terlihat bahwasanya ada peningkatan kompetensi pedagogik guru yang ditemukan dalam kegiatan pengabdian tersebut. Untuk melihat kurva peningkatan kompetensi guru, dapat dilihat pada Gambar 9

Gambar 9 terpapar informasi peningkatan kompetensi guru selama kegiatan pengabdian berlangsung. Kurva berwarna biru merupakan hasil pretest yang dilakukan sebelum dilaksanakan kuliah umum. Kurva coklat merupakan hasil postest setelah dilaksanakan workshop trainer arduino. Kurva abu-abu adalah evaluasi hasil kegiatan yang dilaksanakan 2 minggu pasca kegiatan workshop. Sedangkan kurva kuning merupakan hasil evaluasi hasil pengabdian 1 bulan sesudah kegiatan.

Partisipan yang memperoleh peningkatan kompetensi maksimal pada saat Posttest adalah adalah partisipan 8, 13 dan 15, sedangkan partisipan yang mendapatkan peningkatan kompetensi paling rendah adalah partisipan 10 dan 11.

Untuk melihat persentase peningkatan kompetensi guru secara keseluruhan dapat menggunakan rumus:

$$
\% \text { Peningkatan }=\frac{\text { Nilai akhir-nilai awal }}{\text { nilai awal }} \times 100
$$

Secara garis besar, peningkatan kompetensi signifikan terjadi antara pretest dan posttest. Jika dibandingkan dengan peningkatan pada 2 minggu atau satu bulan sesudah kegiatan, persentase peningkatan kompetensi dari pretest ke posttest sebesar 17, $25 \%$. Peningkatan kompetensi guru dari posteset ke Evaluasi 2 minggu merupakan peningkatan dengan persentase terkecil yaitu sebesar 3,36 \%. Sedangkan persentase peningkatan dari evaluasi 2 minggu ke evaluasi 1 bulan adalah sebesar 5,41 \%. Dari hasil evaluasi sesudah pelatihan dapat ditarik kesimpulan bahwa guru memiliki peningkatan kompetensi yang rendah jika diberikan belajar secara mandiri. 
Tabel 4. Persentase Peningkatan Kompetensi Guru

\begin{tabular}{clccc}
\hline No & Name & Pretest & 1 Month Evaluation & \% Increase \\
\hline 1 & Participant 1 & 52,5 & 77 & 31,82 \\
2 & Participant 2 & 67,5 & 80 & 15,63 \\
3 & Participant 3 & 65 & 80 & 18,75 \\
4 & Participant 4 & 65 & 77,5 & 16,13 \\
5 & Participant 5 & 60 & 80 & 25,00 \\
6 & Participant 6 & 57,5 & 80 & 28,13 \\
7 & Participant 7 & 70 & 85 & 17,65 \\
8 & Participant 8 & 75 & 95 & 21,05 \\
9 & Participant 9 & 60 & 87,5 & 31,43 \\
10 & Participant 10 & 55 & 75 & 26,67 \\
11 & Participant 11 & 52,5 & 75 & 30,00 \\
12 & Participant 12 & 65 & 85 & 23,53 \\
13 & Participant 13 & 62,5 & 90 & 30,56 \\
14 & Participant 14 & 65 & 85 & 23,53 \\
15 & Participant 15 & 70 & 95 & 26,32 \\
Average Increase & & & 24,41 \\
\hline
\end{tabular}

Untuk melihat persentase peningkatan kompetensi guru pada kegiatan pelatihan dan workshop trainer arduino secara keseluruhan, nilai yang digunakan adalah nilai pretest dannilai evaluasi 1 bulan. Pemilihan nilai evaluasi 1 bulan diambil sebagai acuan dalam melihat peningkatan kompetensi guru bertujuan untuk melihat apakah guru tersebut melanjutkan belajar mandiri di sekolah.

Dengan menggunakan rumus diatas, dapat dihitung persentase peningkatan kompetensi guru. Nilai akhir adalah nilai evaluasi 1 bulan sesudah kegiatan. Sedangkan nilai awal adalah nilai pretest sebelum kegiatan dilaksanakan.
Diharapkan dari hasil perhitungan tersebut, tergambarkan persentase peningkatan kompetensi guru khususnya dalam penggunaan mikrokontroler Untuk melihat persentase peningkatan dapat dilihat di Tabel 4 .

Berdasarkan tabel peningkatan signifikan pada partisipan 1 dimana terjadi pengingkatan kompetensi sebesar 31,82\%. Peningkatan dengan persentase terkecil pada partisipan 2 yaitu sebesar 15,63 \%. Rata-rata peningkatan kompetensi guru pada kegiatan pengabdian ini adalah sebesar 24,41 \%. Untuk lebih jelasnya dapat dilihat kurva pada Gambar 10.

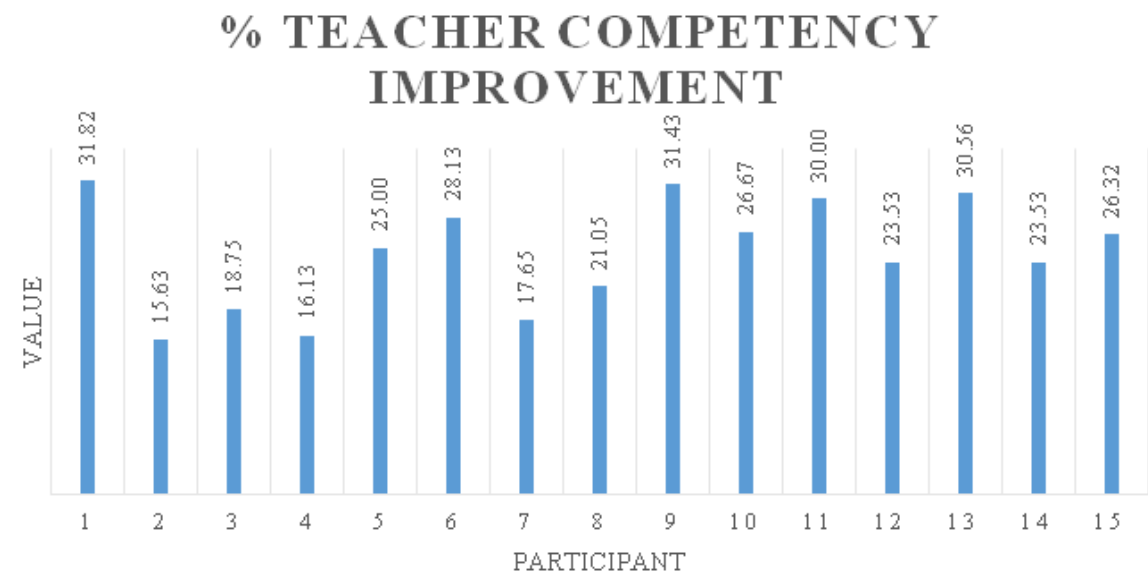

Gambar 10 Persentase Peningkatan Kompetensi Guru 


\section{KESIMPULAN}

Kesimpulan yang dapat diambil adalah dengan pemberian pelatihan Trainer Arduino dianggap berhasil dalam meningkatkan kompetensi guru SMK Multi Mekanik Masmur Pekanbaru. Besarnya persentase peningkatan kompetensi guru adalah sebesar 24,41 \%. Pelatihan trainer Arduino dapat mengupgrade kompetensi guru dalam mempersiapkan diri menghadapi Revolusi Industri V 4.0. dengan pelatihan yang baik, dapat meningkatkan kompetensi guru secara maksimal jika dibandingkan dengan guru belajar secara mandiri.

Saran yang dapat diambil dari penelitian ini adalah sebisa mungkin memberikan pelatihan yang rutin kepada guru. Dengan pelatihan yang baik dan terstruktur sesuai dengan kebutuhan zaman, dapat meningkatkan kompetensi pedagogic guru.

\section{DAFTAR PUSTAKA}

L. LPTIK, "Informasi UU RI No 14 tahun 2005 tentang Guru dan Dosen-UUNo142005 (Guru \& Dosen)," 2005.

\section{A. Sutikno, "UPAYA PENINGKATAN KOMPETENSI GURU MELALUI PENGEMBANGAN DIRI."}

J. M. Tedjawati, “Peningkatan kompetensi guru melalui lesson study: kasus di Kabupaten Bantul," J. Pendidik. Dan Kebud., vol. 17, no. 4, pp. 480-489, 2011.

D. Marwanto, "RANCANG BANGUN TRAINER SENSOR BERBASIS ARDUINO UNTUK MENUNJANG MATA KULIAH INSTRUMENTASI KENDALI DI UNIVERSITAS NEGERI SURABAYA," J. Pendidik. Tek. Mesin, vol. 5, no. 02, 2016.

Onibonoje, M.O., Umeh, U.N., Kehinde, L.O., 2015. Development of an Arduinobased trainer for building a wireless sensor network in an undergraduate teaching laboratory. Int. J. Electr. Electron. Sci. 2, 64-73.

Daftar Alamat dan Jurusan SMK Negeri dan Swasta Kota Pekanbaru. 2017. http://blog.kartunmania. com/2017/10/daftar-alamat-dan-jurusan-smk-negeri-danswasta-kota-pekanbaru/ dikunjungi 2 Mei 2018.

Nurhadi Budi S. 2017. Modul Pengembangan Keprofesian Berkelanjutan, Jakarta 